\title{
Hysteresis in the Third Space? Pupils' and Their Parents' Fitting Process to the Hidden Curriculum of New Literacy Practices
}

\author{
Räisänen, Sari ${ }^{1} \&$ Korkeamäki, Riitta-Liisa ${ }^{1}$ \\ ${ }^{1}$ Faculty of Education, PL 2000, 90014 University of Oulu, Finland \\ Correspondence: Sari Räisänen, PL 2000, 90014 University of Oulu, Finland.
}

Received: March 20, 2018

Accepted: April 6, 2018

Online Published: April 13, 2018

doi:10.20849/jed.v2i1.363

URL: https://doi.org/10.20849/jed.v2i1.363

\begin{abstract}
New literacies offer new spaces for literacy learning and teaching in schools and influence the social structures of the classroom community through the pupils' possibilities for collaboration and communication. The social structures in education are often referred with the concept of hidden curriculum, because the social equities/inequities are indicated in hidden messages, for example in values, attitudes and beliefs. This study explored the hidden literacy curriculum in a Finnish first-grade classroom community experiencing a change of traditional literacy practices towards new literacies. We chose Bourdieu and Gee as our thinking companions because their theoretical concepts involving change and identity building enabled us to gain a better understanding of the phenomena. We followed the pupils' and the parents' ways of fitting to the change. It became evident that the teachers need to support the pupils as well as the parents and to use different tactics for making the change successful.
\end{abstract}

Keywords: change, hidden curriculum, literacy practices, hysteresis, third space

\section{Introduction}

The affordances (Gibson, 1977) of new technologies in learning have become the focus of interest in literacy research and in school development (e.g., Räisänen, 2015). According to the research, not only new technology, but also the social structure, the classroom "ethos", has been identified a factor in defining literacy practices in schools as "new" (Lankshear \& Knobel, 2012). Indeed, the affordances offer new spaces for literacy learning and teaching in schools (e.g., Alvermann \& Heron, 2001; Kist, 2005; Marsh, 2007; Selander \& Kress, 2010) and influence the social structures of the classroom community through the pupils' possibilities for collaboration and communication (see Räisänen, 2015).

The obstacles for change from the traditional teacher-directed practices towards pupil-centred and more emancipatory ones can be found in the difficulty to observe and to define the social structure in a classroom community because the way social equity/inequity is reproduced in the classroom is mostly indicated in hidden messages. These hidden messages are defined in educational contexts by the concept of hidden curriculum (see Bourdieu \& Passeron, 2000; Cotton, Winter, \& Bailey, 2013; Edwards, 2014). The hidden curriculum is understood as almost impossible to reproduce because of the deterministic perspective actors in education have; the belief is that the structures need be changed, but the structures, prevent the change (Cotton et al., 2013). Therefore, in order for change to succeed, it is essential to enhance the teachers' awareness of the factors in the social structure - in the hidden curriculum (see Alsubaie, 2015; Cotton et al., 2013)

This study explores the hidden literacy curriculum in a Finnish first-grade classroom community in the change of traditional literacy practices towards an emancipatory learning environment (see e.g., Grundy, 1987). The new practices afforded a change in the social structure as they deviated from the traditional teacher-directed literacy practices in Finland (Räisänen, 2015). That is, the change in the practices involved a reproduction of the hidden curriculum. In this study we aim to enhance our understanding of the reproduction process in practice with the help of theoretical companionship of concepts by Bourdieu $(1977,1990)$ and Gee $(1990,1996)$. We use the concepts as tools to open up the challenging character of the hidden curriculum. We also discuss our understanding of how the concepts work in enhancing awareness of the change in the hidden curriculum. We have chosen to study more closely how pupils and parents experience the change, although we do not ignore the teacher's agency in relation to these experiences. We are aware of cultural context of our study; however, the 
elements of the change process apply also to other cultural contexts, where pedagogies and practices are challenging. Thus, the study offers possibilities for professional learning concerning the hidden curriculum.

\section{Theoretical Companions of the Study: Bourdieu and Gee}

We chose as our theoretical thinking companions Bourdieu's $(1977,1990)$ concepts of habitus and hysteresis and Gee's $(1990,1996)$ concept of Discourse, which we understood to intertwine with each other. Indeed, researchers have lately been encouraged in this kind of reconstructing of Bourdieu's concepts as well as integration of them with other influences and experiences (Blommaert, 2015; Robbins, 1998). Together the concepts gave us the tools to learn more about how individuals negotiate changes in the context of the study. Bourdieu's $(1977,1990)$ habitus offered us one perspective to understand the reproduction of social structures. Habitus is a "structured and structuring structure", which generates, organizes and constitutes expectations of social practices, for individuals and their actions (Bourdieu, 1990; Maton, 2012). For example, practices in school are constituted by habitus that involve certain tendencies to act, to be, to feel and to think. These tendencies are culturally embedded over time. However, habitus is not determined; it can be reproduced (Bourdieu, 1977). That is, the social structures the hidden curriculum involves can also be transformed, although these processes are demanding. Likewise, the reproduction of the hidden curriculum requires awareness (Cotton et al., 2013); similarly, change in the habitus is not possible without awareness (Bourdieu, 1977, 1990).

According to Bourdieu (1977, 1990), this kind of change in the social structure always causes tension, which makes the change process a struggle. In the classroom community of this study, the aim for new literacy practices deviated from the culturally constituted habitus and therefore, we expected to observe tension in the individuals' tendencies to act. Bourdieu (1977) used a term called "hysteresis" to describe the transformation of habitus and the tension within it. The effect of the hysteresis of habitus is, that sometimes individuals do not succeed in fitting the old and the new and thus, they drift into confusion (Bourdieu, 1977). As a consequence, they do not know how to be. This uncertainty in the tendencies may even result in social exclusion if the individuals do not recognize the opportunities for success that the new practices offer (Hardy, 2012). There is always a danger of social inequality in the change process, although the aim of the change would be quite the opposite. Therefore, change in the practices, which bring forth new social spaces, can be expected to be a "fitting" process to the hidden curriculum. It may cause tension and confusion among individuals of the community and even difficulties in understanding the way they should be. Additionally, as habitus is always relative (Bourdieu, 1977, 1990), its reproduction too is influenced, for example, by situational factors and the actions of others. In a classroom community, the fitting process is therefore also a relational process between the participants in different situations with diverse tools of learning.

In order to deepen our understanding of the change, we also engaged another thinking companion, Gee (1990) and his concept of Discourse. Discourse is connected to identity building in a certain social role or practice (Gee, 1990; Menard-Warwick, 2005), for example, being a pupil or a teacher in school with a certain kind of literacy identity (Wohlwend, 2011). Discourse has similarities with Bourdieu's $(1977,1990)$ concept of habitus (Curry, 2008). However, Discourse is presenting a kind of membership in social practices, while habitus is embedded in society (e.g., Menard-Warwick, 2005). In the context of this study, the kind of tension that results in the reproduction of habitus in the hidden curriculum, we can understand as a conflict between two differing Discourses. There were simultaneously two differing Discourses in the classroom community, the traditional one and the new one, which the actors (the pupils, their parents and the teacher) took part in simultaneously. From the point of view of our theoretical thinking companions, the conflict affords space for transformation or reconstruction of the individuals' literacy identities and of the hidden curriculum. The conflict of the two differing Discourses Gee (1990) called a "third space". This third space forms a hybrid Discourse (Gee, 1996) where the individuals try to find out the appropriate tendencies to act and to be.

Our understanding, based on our theoretical companions, is that the change process in social structures in the classroom community (involving the pupils, their parents and the teacher) is a third space where the participants try to fit their attitudes, beliefs and values to their new experiences. In this fitting process, their habitus is altering and transforming into something new. The fitting process is not easy; it involves tension, even hysteresis. During the change, there is tension of intertwining different practices (and positions), from which one chooses between different tendencies to act in relation to others. Some participants might experience more obstacles and be more confused than others in choosing their tendencies to act and to be. As we have stated, it is only by becoming aware of and recognising these possible obstacles that the hidden curriculum can be reproduced (see Cotton et al., 2013). Therefore, in this study we became especially interested in individuals' diverse experiences concerning their tendencies to act and to be in the classroom community. We wanted to follow the pupils' and parents' ways of fitting to the hidden curriculum and their ways of coping with the tension and the possible confusion a change 
can create. We also paid close attention to the teacher's agency in the fitting process in relation to the pupils and their parents because it is the teacher who utilizes the hidden curriculum (Alsubaie , 2015).

\section{Method}

The theoretical concepts, the practice and the method of this study are inseparable. The theoretical concepts challenged us to question and to study the change in literacy practices as a fitting process and the methodological strategy we used, Nexus Analysis (NA), helped us analyse and interpret these processes. NA highlights the researcher's participation to the nexus of practice, the group being studied, for understanding the changes in the social actions of the participants. In this study, the teacher, who worked in the first-grade classroom is also the first author of the study. The second author supervised the teacher during the research process.

NA is based on several theoretical constructs including habitus and Discourse (Norris \& Jones, 2005; Scollon \& Scollon, 2004). Indeed, habitus works as an analytic tool for researching situational education practices (Grenfell \& James, 1998a, 1998b) and offers possibilities for studying the relationships between identity, texts and practices (Pahl, 2008). Habitus was important for us when we concentrated on how the individuals participating in the classroom community experienced their being and acting in the change the teacher aimed for in the practices. Moreover, it helped us to understand the relations during the fitting process. The concept of Discourse (Gee, 1996) offered us understanding of the third space of the classroom community. All the individuals (pupils, parents and teachers) had certain culturally embedded expectations (habitus) for literacy practices and their actions were relational, influencing each other. In the third space, they all tried to fit their expectations with their new experiences. These fitting processes involved a certain amount of tension and a possibility of not finding a way to fit to the new practices, that is, ending up to hysteresis (Bourdieu, 1977).

\subsection{The Classroom Context}

There were 18 pupils in the first-grade classroom community (10 boys and eight girls, aged 7-8). The physical environment of the classroom was organized to fit to the new literacy practices (see Räisänen, 2015; for material elements see e.g., Pahl \& Rowsell, 2010). Traditionally, in Finnish classrooms, the teacher's desk is placed in the front of the classroom, and the pupils' desks are arranged in rows facing it (Kuuskorpi, 2012). In the classroom in question, the desks were organised into five groups; there were also six working places with a computer, a small classroom library with a sofa and a corner for art work. In addition, the teacher had made changes to the timetable. The literacy lessons could vary in length instead of being divided to Finnish traditional 45-minute lessons. Furthermore, instead of whole class activities, there were several activities available simultaneously and the activities could vary in length. The pupils participated in several larger projects during the school year. For example, they designed board games, made an animation and created an imaginary bakery blog site. In these projects, the pupils used technological tools other than computers, such as digital and video cameras.

From the very beginning of the school year, the teacher aimed to change the teacher-directed instruction and to enhance the pupils' collaboration. They worked mostly in pairs or in small groups. Each group had more and less competent peers following Vygotsky's (1978) theory of socio-cultural learning and the zone of proximal development. Some pupils needed a specific kind of pair in order to concentrate or to interact. Learning the code was derived from Trageton's (2006) model in Norway, in which children start processing coding by writing, for example, letter strings with computers. The pupils worked in pairs and supported each other's learning of sound/letter correspondence by using invented spelling (e.g., Clay, 1991; Sulzby \& Teale, 1991). The pupils worked similarly after they had cracked the code.

In the classroom library, the pupils read books with their peers or alone according to their skills. They could browse in the pages, view the illustrations, use memorisation, make up texts or sound out words. The reading was thus characterized by reading-like behaviour (Sulzby \& Teale, 1991). Shared stories were an important part of the reading practices. The pupils had also possibilities for playing and for drama activities. The parents were invited to take part in lessons and to visit the classroom. The teacher kept in touch almost daily with parents via email and by sending, for example, photographs presenting the created text products.

\subsection{The Data Production and Analysis}

The data of the study consisted of video recordings from the classroom literacy events and questionnaires for the parents. These data completed each other and gave us information about the hidden curriculum and about how different individuals coped with the change. The data analysis, and likewise the whole study, was a process in which our focus moved from following the whole classroom community to two individual pupils and their parents. The data enhanced our awareness about the complexity of the fitting process to the hidden curriculum afforded by the new practices. In the results and discussion, we elaborate our findings and give examples of the 
different kinds of tendencies to acting and being in the new situation. Simultaneously, we also discuss the findings in the light of theoretical concepts we have chosen to use in the study and in the light of former research, which enhances the understanding of actions in the third space. It must be noted that similar kinds of situations as in the excerpts most likely occur in most of first-grades whether new practises are implemented or not because to fit into the school practices is always a dramatic change in a child's life. However, we have aimed for concentrating on the tension between the culturally embedded practices and the new ones with the help of our theoretical concepts. We wanted to explore whether this approach could offer us new insights into implementation and development work in classroom communities in the area of new literacies.

\subsubsection{Video Recordings}

During the school year, the teacher video recorded literacy events or activities (Barton \& Hamilton, 2000) involving literacy practices of reading, writing and playing. The teacher participated in these events and thus, she did not only collect the data, but produced it together with her pupils. The video recordings included video clips (a total of 26 hours 18 minutes), which captured the relevant actions of the pupils and the teacher. Because the teacher had the role of teacher-researcher, the data production was challenging, as she needed often to change her plans to video record because of the hectic classroom work. Sometimes she did not remember to put the video camera on at all, and sometimes she filmed events she had not planned to include. We viewed the video recordings and transcribed those instances that reflected the most common actions of pupils during the school year. We organised these transcriptions into chronological order.

In transcriptions, two pupils gained our particular attention. Milla (a girl) and Joni (a boy), could not read or write conventionally when the school year began, and they worked quite often as a pair. The transcriptions revealed that most of their actions reflected the most common "learning to read" practices in the whole classroom community. From the transcriptions, we analysed the macro-structure units of interaction or sequences of sentences (van Dijk, 1977a, 1977b, 1980) as well as the micro-structure units of specific words or sentences (e.g., Bloome et al., 2005) that the pupils and the teacher used in order to express their positions, values, beliefs, attitudes, procedures, norms, expectations, behaviours - the elements of hidden curriculum. We concentrated therefore not as much on the literacy practices themselves, but on the social affordances of the practices, although we could not totally ignore the practices. Furthermore, as habitus (Bourdieu, 1977, 1990) involves all human actions, we analysed the physical actions (e.g., putting hands over one's own work so that nobody else could see it or moving around in the classroom). Based on this analysis, we were able to recognise elements, which described the pupils' fitting processes and their acting and being in the third space.

\subsubsection{Questionnaires for the Parents}

The teacher met the parents of each pupil four times during the school year to discuss the practices and their child's learning. For these discussions, the parents first answered a questionnaire concerning their child's reading, writing (handwriting and working with computers) as well as other aspects of being a pupil. In three of the questionnaires (the first, the third and the last) there were arguments about reading, such as "My child likes books" and "My child has developed in reading", which the parents were supposed to agree or disagree with. Similar kind of arguments concerned writing. In all the four questionnaires, there were open-ended questions for parents to answer about the literacy practices and their children's learning process. Because the parents we expected to discuss these issues with their children before answering, in these open-ended questions, the voices of the pupils were also acknowledged.

We examined and read thoroughly the questionnaires that Milla's and Joni's parents answered. We searched from the answers interrelations to Milla's and Joni's actions and being in school by concentrating both macroand micro-structure units, which would tell us how the practices in the classroom were experienced in their home environments. We filtered units, which gave us information about the pupils' and the parents' fitting processes, that is, if there was tension or confusion about the practices or if there was evidence that the individuals were fitting successfully to the practices of the classroom.

\section{Results and Discussion}

We first present and discuss how Milla's and Joni's fitting processes were alike, what kinds of elements were involved and how the teacher's acting and being was related to Milla's and Joni's processes. Then we present and discuss how the change was experienced from a perspective of Milla's and Joni's parents. We present two excerpts from several similar ones from the data to describe those actions and tendencies, which we found as the most significant to Milla's and Joni's fitting processes as well as which of these processes mirror the whole classroom community. It must be noted, that there was often more than one way to interpret the tendencies to act in the classroom and therefore we have tried to present several different insights in order to address this problem. 


\subsection{Milla and Joni}

Milla's and Joni's actions varied in the ways they dealt with the new ways of working (collaboration, producing and using diversified texts instead of practicing mere spelling exercises) and more traditional ones. That is, there was a slight tension regarding how to act and to be; there were tendencies to fit to the old culturally-embedded practices and tendencies to fit to the new ways of working. To discuss more about this third space (Gee, 1997), we chose to present the following Excerpt 1, from August 31 in which Milla and Joni are producing together traffic rules by writing with a computer at the very beginning of the school year. The teacher had given instructions for content and for ways of working to the whole class before the project began. Milla was sitting in front of a computer, and Joni stood beside her. The teacher came to look at their work.

Excerpt 1, August 31

1 Milla: We do not know at all what to write.

2 The teacher: What did you plan to write? For example "Do not run into the street"?

3 Milla: Yes.

4 The teacher: With what letter does it start? Äääl ... (sounds out in the Finnish language).

5 Milla: Ääää ... (Joni presses the letter ä from the keyboard).

6 The teacher: Ok. Put the caps lock on (puts it on). What's next?

7 Joni: Äääll11l ... (repeats several times and presses the letter "l").

8 The teacher: Write those letters you are able to hear when you are sounding out. Think together. Joni, you should write together with Milla.

9 Joni: I cannot.

10 The teacher: I am sure you can. (Joni goes down and sits on the floor.)

11 Milla talking to Joni: Come to see now.

12 The teacher to Joni: If you find it hard to be here, we will find something else to do.

13 Joni: I can work here (stands up).

14 The teacher: Write like I guided you.

15 Milla: Listen (says the word they want to write).

16 The teacher: Listen uuuu ... (Joni looks around). Joni, you could help Milla with this.

17 Milla: Peee ... (sounds out, Joni presses the key).

18 Joni: Is it "p" or "b"?

19 Milla: Who cares? (Milla swipes her hand in the air. Both pupils continue working. Milla is writing and Joni is sounding out.)

20 The teacher reads the text: "To obey your teacher" ... Is it a traffic rule? (smiles).

21 Milla: No.

22 The teacher: You can leave it there if you want to (smiles. Milla smiles too and looks at Joni).

In the Excerpt 1, Milla and Joni both tried to figure out in their own way how to act in the classroom community. First, we observed that they were uncertain about what they were supposed to do and how. Thus, they sought support from the teacher (line 1). Joni even stated to the teacher that he couldn't do the task (line 9) and was physically restless (line 10). Joni obviously had knowledge about sounds and letters (line 18), but he needed the teacher to guide him more concretely. Indeed, Joni experienced the confusion quite strongly (lines 9 and 10). The teacher answered this need and tried to determine the right kind of support for Joni. She offered him another kind of a task (line 12), which indicated that she was not sure how to cope with Joni's needs versus her aim to make a move towards pupil-centred learning. The teacher tried to choose between these tendencies, and finally Joni made a decision of as he expressed that he wanted to continue writing with Milla (line 13).

It was not yet, at the time of the event in the Excerpt 1, clear for the teacher what she expected from the pupils. Like her pupils, she was figuring out her role (see Räisänen, 2015). Her responsibility was to offer support and guidance (Genish \& Dyson, 2009), but to do it in a non-dominating way, which was a tough combination. The pupils' tendencies to act and the teacher' responses to these tendencies varied according to situational factors creating a third space for literacy learning and teaching. The fitting process became relational. The pupils were 
confused about the teacher's role; they could not "read" her behaviour nor could they quite understand the space and the power they were offered in expressing their own ideas and knowledge. This confusion was indicated also as they wrote "To obey your teacher" (line 20) to their traffic rules. It was like Milla and Joni expected the teacher to be "the one who knows". They also wanted the teacher to tell them "what" to write (line 1), setting the teacher in the centre of the practice and the teacher, also confused, responded similarly to this traditional expectation of a teacher's role.

However, it can also be interpreted that the teacher had to act in a teacher-directed and technical way when the pupils wanted support. This kind of a technical instruction is needed for building up the community structure, although it should not dominate the classroom community and the teachers should aim to minimize it (see Grundy, 1987). In Excerpt 1, the teacher tried to move the focus from herself to the pupils as she instructed them to work together by sounding the letters and composing the traffic rules (e.g., lines 8,14 , and 16), which was an important step in reproduction of the hidden curriculum as the pupils, in this way, gradually learned to work together. Simultaneously, this small move during one event evidenced that the teacher consciously wanted to influence the confusion; she tried to find her way out of hysteresis (Bourdieu, 1977). The teacher had to be the one who made it clear for herself and for the pupils the ways of working in the classroom. Indeed, this kind of pedagogical behaviour is essential for successful educational improvement (e.g., Horne \& Brown, 1997).

Excerpt 1 is one example that illustrated that it was easier for Milla than for Joni to fit her expectations into the new practices. Milla took the responsibility of the task by encouraging Joni to listen to the sounds (e.g., Excerpt 1, line 15). Milla showed Joni that it didn't matter if they did not get the right letters if they just keep processing the words when Joni wanted to know if the right letter for the sound was "p" or "b" (lines 18 and 19). On the other hand, Milla's unwillingness to discuss or elaborate the sound with Joni might indicate that she did not know exactly what was expected from her as a pupil. She was not yet ready for negotiation with her peer, which is an important part of collaborative learning (e.g., Mercer \& Littleton, 2007). Overall, during the school year, Milla made up rules and decided for both of herself and Joni. She "ruled" the power relation "game" that was played (for "game", see Bourdieu, 1990). Milla's attempt to take the power might have irritated Joni, who was quite dependent on the teacher and searched for her support as he, during the school year, was observed breaking the rules Milla had made (e.g., September 9) by bringing up that the teacher was the only one to obey and to negotiate with. Thus, the power structures of the hidden curriculum were negotiated through the rules in the classroom community. At that level, the 'making up' of rules (taking over the game) actually reflected the pupils' actions throughout the school year, although the rules transformed from "what one is allowed to do" to "how one is allowed to act".

Indeed, the third space established the pupils' power position, which they were adapting from the culturally embedded ways of acting in a classroom community. When the teacher aimed to give up her teacher-directed tendencies, the pupils took over this traditional role. According to Thornberg (2009), in rules there are also embedded expectations of "a good pupil". Thus, the pupils had a need to make rules for their working, and they based these rules on their a priori assumptions of the schoolwork. That is, they assumed that there was only one solution for every problem, like in the traditional learning environment where the teacher is expected to have all the solutions. This assumption made it problematic for pupils to compromise and to accept that the solution the other pupil had was just as good and acceptable as any other. It was also a question of gaining solid status, of being an appreciated member of the classroom community and not being excluded (Wohlwend, 2011). In the Excerpt 1, Milla's way of acting as an encouraging peer and simultaneously making decisions for Joni could also be interpreted as her way of gaining this status.

Milla was also clever in inventing a way to make her look like a competent reader as she read on her own way by using reading-like behaviour (Sulzby \& Teale, 1991) with nonsense words while reading a Calvin and Hobbes comic book (September 15). She told to the astonished listeners including Joni that she read in Swedish (Swedish is the second official language besides Finnish in Finland. The pupils in the classroom had not Swedish as their mother language). Joni encouraged Milla to continue her reading and acted as a supportive peer. Milla self-made her reading as a sign of "a good pupil" and simultaneously this action gave her status (Wohlwend, 2011). That is, she fitted her identity with the classroom environment and the new practices, although she might have felt that nonsense was not totally appropriate, when she explained that she read in Swedish.

For being "a good pupil" and to enhance their status in the classroom community of this study also involved a kind of competition (Wohlwend, 2011). The pupils had a habit of comparing the length of the texts as evidence that somebody had done better work than someone else. This need to compare strength and skills is a sign of situational masculinity (Wohlwend, 2011). However, we observed that it was not only the boys who competed as the girls did that too. We observed also that the teacher might have unconsciously supported the competition as 
she often responded to the pupils' comments with a happy voice saying how pleased she was about the amount of writing (e.g., November 11). She also empowered the pupils this way, although she might not have recognized it (also see Wohlwend, 2011). Thus, the freedom the pupils had was a sort of illusion in the classroom community (Bourdieu, 1998).

Although Milla and Joni were obviously balancing between the old and the new practices, there were simultaneous indicators during the year that showed that Milla and Joni, the other pupils and the teacher were all succeeding in their fitting process. This is quite natural outcome; however, from the perspective of the hidden curriculum, it became obvious that the equality within the community was strengthened. The teacher clearly let the pupils make more decisions and the collaboration with peers was enhanced. Joni started to accept guidance and solutions from his peers (November 2) and not only from the teacher. Milla showed certainty of her own knowledge - not relying on the teacher - and did not focus on taking over the power by herself but together with her peers. For example, while playing a cashier in a supermarket role play on April 27, she told the teacher that she and her peers together had reduced item prices because they thought they were too expensive. While at the beginning of the school year, the pupils expected the teacher "to rule" (and to have the power), at the end of the school year, the pupils discussed and solved problems together.

That is, the data indicated that the pupils and the teacher moved from their previous expectations and were more open to other solutions. This move brought also joy for the pupils, as their confusion diminished and they became sure about what was expected from them. In the Excerpt 2, November 2, Joni expressed the joy that certainty brought to him. In the Excerpt 2, four pupils were making preparations for video recording a quiz about Christmas. They were to write together a sentence about Christmas and then draw a picture of it to the black board. The group decided to write "The Santa comes down through the chimney". Joni doubted his drawing skills.

\section{Excerpt 2, November 2}

1 Joni: I cannot draw a chimney.

2 The teacher: You can draw just the way you can.

3 Joni: Jee! (happily)

In Excerpt 2, Joni needed the teacher to encourage him to use his own skills (line 2), which he received with enthusiasm (line 3). Joni sussed what was expected from him, which allowed him to know how to be.

The tension Milla, Joni and the teacher coped with was an essential part of the process in their adjustment to the new literacy practices. As we have seen in the interpretation process of the data, Milla and Joni had slightly different ways of coping with their tendencies. Even their learning processes differed; Milla learned coding and decoding skills quite soon after school began; Joni instead needed more support from the teacher and from the other pupils and learned conventional skills approximately in the middle of the school year. Joni's confusion (not knowing how to be and act) could have led to an unsuccessful fitting process if the teacher had not realised that she could not let go of teacher-directed instruction totally. That is, the teacher, Milla, and Joni all produced their own tactics (Wohlwend, 2011). Similarly, all the pupils had their individual tactics in the classroom community, which allowed them to "make do" with the resources available by remaking the space for literacy learning and to act according to their particular purposes in particular situations (Wohlwend, 2011, p. 114). With the support of and relation to the teacher and their peers, the pupils fitted the new practices into their habitus (Bourdieu, 1977, 1990). The teacher had to regulate her own actions and her being in the situations of the classroom and in the light of her aim to change the practices. The way the pupils handled the confusion, hysteresis (Bourdieu, 1977, 1990), in the third space was a process, which could not have been predicted. It happens in continuous negotiation of power relations within the classroom community and during identity performances of the pupils and the teacher in this social space (Wohlwend, 2011) forming the hidden curriculum (see e.g., Edwards, 2014).

\subsection{Joni's and Milla's Parents}

Joni's parents' answers to the questions indicated strongly that they experienced the confusion the new practices brought to the classroom discourse. In the first questionnaire, they expressed that Joni had good skills when working with a computer, that he did not need any help, that writing was easy for him, that he liked to work with the computer and that he had learned a lot. On the other hand, they expressed that Joni became easily frustrated, needed help from them while writing by hand and had not progressed in his literacy skills, especially in reading. Working with the computer had caused confusion in Joni's home and was seen as a separate action that had very little to do with his literacy skills. This may have had to do with the parents' understanding of their child as "digital natives" (Prensky, 2001) because Joni's parents experienced Joni as a competent computer user, but it 
was confusing to use the computer as a tool for learning reading and writing. The parents were therefore confused about how to support their child and they expressed in the questionnaires that they would have appreciated more traditional tools such as a traditional textbook.

In the questionnaires from the spring term, Joni's parents' confusion seemed to become more intense. They had noticed that Joni was motivated to read and to write, but got easily angry if they told about misspellings. The parents indicated that they found it hard to understand their role in supporting Joni because they experienced that it was important to read and to write flawlessly at home although (or because of?) Joni did not do that at school. The parents could not understand the new ways of learning. Simultaneously, they felt that Joni had learned a lot during his first school year and there was nothing that worried them about his learning. The experience of hysteresis (Bourdieu, 1977) was therefore strong - the parents did not know how or what to think and it was also hard for the teacher to follow their thinking.

The answers from Milla's parents were very different. Their experience was that Milla liked literacy in school and at home and that she liked to read books and to write, and they were not bothered if she made mistakes. Milla's parents' answers were similar to her actions in the classroom. Milla was in a similar situation both in school and at home; she was allowed to work in similar ways in these both environments. Milla had it easy to choose between the tendencies to act and to be, while Joni was driven to many tendencies simultaneously. That is, the hysteresis did not involve for Milla as much tension and confusion as it did for Joni.

The confusion Joni's parents' responses revealed was evident in Joni's actions in the classroom. He was uncertain of his actions and needed constant support, especially at the beginning of the school year. Milla was able to help him, because she adapted quickly as to what was expected from her. Joni found it difficult to accept that he was free to use his emerging knowledge and skills; he insisted on waiting for them to become perfect. Gradually he became excited about the accomplishments he made at school and felt joy although there was a mismatch with the expectations in school and home. The mismatch made him confused, which in turn may have caused obstacles for his learning process. As a result, the third space Joni, the teacher and the parents were involved in, was a risk factor for a successful change.

When we pondered the confusion the change afforded in the classroom community and the reasons why some individuals felt it more strongly, we came to the conclusion that the teacher's role is essential. The teacher needs to fit to the practices as soon as possible to be able to support and to guide not only the pupils but the parents. The teacher should have offered more support for this family as soon as she noticed the parents' and Joni's preferences for traditional practices.

\section{Conclusions}

This study suggests that the teachers need a significant level of awareness, knowledge and learning when coping with the hysteresis (Bourdieu, 1977, 1990) the change in the practices will bring out in whole classroom community. The teachers need to support the pupils as well as the parents and to evaluate and to use different tactics for working with each individual to avoid unsuccessful fitting processes. Especially important thing is to plan tactics with pupils who are low-performing and do not have the right kind of support from their parents. That is, strategically low-performing pupils experience more confusion and experience greater lack of motivation than others and thus, they need more support in their learning processes (Kontturi, 2016). This study also shows that support at home for pupils plays an important role in building the "learner identity". The change in literacy practice is a process of negotiation and of rebuilding identities for the pupils, their parents and the teacher in the hybrid space of the classroom society.

However, despite the fact that the process of change may sound difficult and hard for both the teachers and the pupils, to stay firmly entrenched in traditional practices is not an option in the contemporary world. Not to mention that the traditional practices may have severe consequences. For example, Stipek, Feiler, Daniels and Milburn (1995) found out when comparing traditional preschools and kindergartens to child-centred ones, that the children in traditional academic programs were more dependent on teachers, showed less pride of their accomplishments, rated their abilities lower and worried more about school. That is, more research is needed in similar circumstances to determine how cultural expectations influence children and how these expectations can be altered in school through the actions of teachers.

We strongly encourage other researchers to develop new ways in integrating the theoretical concepts of habitus, hysteresis (Bourdieu, 1977, 1990) and Discourse (Gee, 1997) as well as linking these concepts with new pupil-cantered concepts. Although our reconstructing and integration of the theoretical concepts gave us the tools to understand how changes in practices are experienced as part of the hidden curriculum and by different individuals, one might argue, that the individual actions were only negotiations of uncertainty led by personal 
characteristics. However, the kind of analysis presented in this article could be useful for teachers in practice, as these tools give knowledge about the individual struggles and therefore, can offer understanding of each individual's needs for support in their fitting and learning processes. That is, the tools have the possibility of helping to recognise those situations when the teacher needs to make an intervention in the learning process in order to keep it on the right track.

\section{Acknowledgements}

This research was supported partly by a grant from the University of Oulu, Faculty of Education.

\section{References}

Alsubaie, M. A. (2015). Hidden Curriculum as one of Current Issues of Curriculum. Journal of Education and Practice, 6 (33), 125-128.

Alvermann, D. E., \& A. H. Heron. (2001). Literacy Identity Work: Playing to Learn with Popular Media. Journal of Adolescent \& Adult Literacy, 45 (2), 118-122.

Barton, D., \& M. Hamilton. (2000). Situated Literacies: Reading and Writing in Context. London, New York: Routledge.

Blommaert, J. M. E. (2015). Pierre Bourdieu and Language in Society. Working Papers in Urban Language and Literacies $153 . \quad$ Retrieved from https://www.academia.edu/10769952/WP153_Blommaert_2015._Pierre_Bourdieu_and_language_in_s ociety

Bloome, D., S. P. Carter, B. M. Christian, S. Otto, \& N. Shuart-Faris. (2005). Discourse Analysis and the Study of Classroom Literacy Events: A Microethnographic Perspective. Mahwah, NJ: Lawrence Erlbaum Associates.

Bourdieu, P. (1977). Outline of a Theory of Practice. Cambridge: Cambridge University Press. https://doi.org/10.1017/CBO9780511812507

Bourdieu, P. (1990). The Logic of Practice. Stanford, CA: Stanford University Press.

Bourdieu, P. (1998). Practical reason. Stanford, CA: Stanford University Press.

Bourdieu, P., \& J-C. Passeron. (2000). Reproduction in Education, Society and Culture. London: SAGE.

Clay, M. (1991). Becoming Literate: The Construction of Inner Control. Portsmouth, NH: Heinemann.

Cotton D., J. Winter, \& I. Bailey. (2013). Researching the Hidden Curriculum: Intentional and Unintended Messages. Journal of Geography in Higher Education, 37 (2), 192-203. https://doi.org/10.1080/03098265.2012.733684

Curry, M. J. (2008). A 'head start and a credit'. Analyzing Cultural Capital in the Basic Writing/ESOL Classroom. In J. Albright \& A. Luke (Eds.), Pierre Bourdieu and Literacy Education (pp. 279-298). New York: Routledge.

Edwards, R. (2014). Software and the Hidden Curriculum in Digital Education. Pedagogy, Culture \& Society. https://doi.org/10.1080/14681366.2014.977809

Gee, J. P. (1990). Social Linguistics and Literacies: Ideology in Discourses. London: Falmer Press.

Gee, J. P. (1996). Social Linguistics and Literacies: Ideology in Discourses (2nd ed). London: Taylor \& Francis.

Genishi, C., \& A. H. Dyson. (2009). Children, Language and Literacy: Diverse Learners in diverse Times. Columbia University: Teachers College Press.

Grenfell, M., \& D. James. (1998b). Theory, practice and pedagogic research. In M. Grenfell \& D. James (Eds.), Bourdieu and Education: Acts of Practical Theory (pp. 6-26). London: Falmer Press.

Grenfell, M., \& D. James. (Eds.). (1998a). Bourdieu and Education. Acts of Practical Theory. London: Falmer Press.

Grundy, S. (1987). Curriculum: Product or Praxis? London: Routledge.

Hardy, C. (2012). Hysteresis. In M. Grenfell (Ed.), Pierre Bourdieu: Key Concepts (pp. 126-145). CT: Acumen. https://doi.org/10.1017/UPO9781844654031.012

Horne, H., \& S. Brown. (1997). 500 Tips for School Improvement. London: Routledge. 
Kist, W. (2005). New Literacies in Action: Teaching and Learning in Multiple Media. New York: Teachers College Press.

Kontturi, H. (2016). Oppimisen itsesäätelyn ilmeneminen ja kehittymisen tukeminen alakoulun oppimiskontekstissa [The occurrence and promotion of self-regulated learning in a primary school learning context] ( $\mathrm{PhD}$ diss.). Finland: University of Oulu, Faculty of Education.

Kuuskorpi, M. (2012). Tulevaisuuden fyysinen oppimisympäristö: käyttäjälähtöinen muunneltava ja joustava opetustila [Future physical learning environment: user-oriented flexible and changeable teaching spaces] (PhD diss.). Finland: University of Turku.

Lankshear, C., \& M. Knobel. (2012). 'New' Literacies: Technologies and Values. Revista Teknokultura, 9, 45-69.

Marsh, J. (2007). New literacies and Old Pedagogies: Recontextualizing Rules and Practices. International Journal of Inclusive Educatio, 11 (3), 267-281. https://doi.org/10.1080/13603110701237522

Maton, K. (2012). Habitus. In M. Grenfell (Ed.), Pierre Bourdieu: Key Concepts (pp. 48-64). CT: Acumen. https://doi.org/10.1017/UPO9781844654031.006

Menard-Warwick, J. (2005). Both a Fiction and an Existential Fact: Theorizing Identity in Second Language Acquisition and Literacy Studies. Linguistics and Education, 16, 253-274. https://doi.org/10.1016/j.linged.2006.02.001

Mercer, N., \& K. Littleton. (2007). Dialogue and the Development of Children's Thinking: A Sociocultural Approach. London: Routledge.

Merchant, G. (2010). 3D Virtual Worlds as Environments for Literacy Learning. Educational Research, 52(2), 135-150. https://doi.org/10.1080/00131881.2010.482739

National Board of Education. (2014). Established Draft for Core Curriculum for Basic Education 2016. Helsinki, Finland: Board of Education. Retrieved from http://www.oph.fi/ops2016/perusteluonnokset

Norris, S., \& H. J. Jones. (2005). Discourse in Action. Introducing Mediated Discourse Analysis. New York: Routledge.

Pahl, K. (2008). Tracing Habitus in Texts: Narratives of Loss, Displacement and Migration in Homes. In J. Albright \& A. Luke (Eds.), Pierre Bourdieu and Literacy Education (pp. 187-208). New York: Routledge.

Pahl, K., \& J. Rowsell. (2010). Artifactual Literacies. New York: Teachers College Press.

Räisänen, S. (2015). Changing Literacy Practices. A Becoming of a New Teacher Agency. Acta Universitatis Ouluensis, E, 153.

Robbins, D. (1998). The need for an Epistemological 'Break'. In M. Grenfell \& D. James (Eds.), Bourdieu and Education: Acts of Practical Theory (pp. 27-51). London: Falmer Press.

Scollon, R., \& S. W. Scollon. (2004). Nexus Analysis. Discourse and the Emerging Internet. Routledge: London.

Selander, S., \& G. Kress. (2010). Design för lärande - ett multimodalt perspektiv [Design for Learning - A Multimodal Perspective]. Stockholm, Sweden: Norstedt.

Stipek, D., R. Feiler, D. Daniels, \& S. Milburn. (1995). Effects of Different Instructional Approaches on Young Children's Achievement and Motivation. Child Development, 66 (1), 209-223. https://doi.org/10.2307/1131201

Sulzby, E., \& W. Teale. (1991). Emergent Literacy. In R. Barr, M. L. Kamil, B. Mosenthal \& D. Pearson (Eds.), Handbook of Reading Research (Vol. 2, pp. 727-757). New York: Longman.

Swartz, D. L. (2002). The Sociology of Habit. The Perspective of Pierre Bourdieu. The Occupational Therapy Journal of Research, 22, 615-695. https://doi.org/10.1177/15394492020220S108

Thornberg, R. (2009). The Moral Construction of the Good Pupil Embedded in School Rules. Education, Citizenship and Social Justice, 4, 245-261. https://doi.org/10.1177/1746197909340874

Trageton, A. (2007). Lukemaan oppiminen kirjoittamalla [Writing to read]. Juva, Finland: PS-kustannus.

van Dijk, T. A. (1977a). Pragmatic Macro-structures in Discourse and Cognition. In M. T. de Mey \& Communication and Cognition Firm (Eds.), CC 77 (pp. 99-113). Netherlands: University of Ghent. 
van Dijk, T. A. (1977b). Text and Context. Explorations in the Semantics and Pragmatics of Discourse. London: Longman Group Ltd.

van Dijk, T. A. (1980). Macrostructure. An Interdisciplinary Study of Global Structures in Discourse, Interaction, and Cognition. Hillsdale, NJ: Lawrence Erlbaum Associates.

Vygotsky, L. S. (1978). Mind and Society. The Development of Higher Psychological Processes. Cambridge, MA: Harvard University Press.

Wohlwend, K. E. (2009). Damsels in Discourse. Girls Consuming and Producing Gendered Identity Texts through Disney Princess Play. Reading Research Quarterly, $44 \quad$ (1), 57-83. https://doi.org/10.1598/RRQ.44.1.3

Wohlwend, K. E. (2011). Playing Their Way into Literacies: Reading, Writing, and Belonging in the Early Childhood Classroom. New York: Teachers College Press.

\section{Note}

Note 1 . The names of the pupils in the article are pseudonyms.

\section{Copyrights}

Copyright for this article is retained by the author(s), with first publication rights granted to the journal.

This is an open-access article distributed under the terms and conditions of the Creative Commons Attribution license (http://creativecommons.org/licenses/by/4.0/). 